\title{
Hubungan Dukungan Orangtua dan Harga Diri dengan Harapan sebagai Variabel Mediator

\author{
Denise Permatasari
} \\ Denise_permatasari@yahoo.com
}

\author{
Magister Psikologi, Universitas Muhammadiyah Malang
}

\begin{abstract}
This study aims to determine the relationship between parental support and self-esteem in the hope as a variable mediator. Research subjects are adolescents ranging from 12-15 years in junior high school Kartika IV-8 Malang as many as 50 subjects. The study used a quantitative method using the Rosenberg Self Esteem Scale to measure self-esteem, Parents as Social Context Questionnaire (PASCQ) Child Report to measure parental support, and Hope Scale for Children to measure hope for children. The analytical method used multiple regression analysis with sobel test to verify the result of mediation. The results of the analysis indicate that there is a direct impact between parental support and self-esteem in adolescents with significant $B=0.693 ; P<0.001$. In addition, hope was found to be a significant mediator in the relationship between parental support and self-esteem of $Z=2.884$.
\end{abstract}

Keywords : parental support, self esteem, hope, adolescents 


\section{PENDAHULUAN}

Pada masa perkembangan anak menjadi remaja, anak akan mengalami perkembangan pada bagian fisik, kognitif dan sosioemosi (Santrock, 2007). Pada perkembangan sosioemosi remaja akan tumbuh menjadi sosok yang lebih emosional dan sensitif terutama pada permasalahan yang menyangkut harga dirinya. Apa yang diucapkan oleh lingkungan sekitarnya kepada remaja secara tidak langsung akan membentuk persepsi remaja mengenai dirinya, lingkungannya, dan bagaimana orang di sekelilingnya melihat dirinya. Persepsi harga diri merupakan keseluruhan cara yang digunakan untuk mengevaluasi diri dan pembanding antara ideal self dengan real self (Santrock, 2007) sehingga dalam masa perkembangan masa remaja, sangatlah penting remaja mengembangkan harga diri yang ia miliki. Banyak faktor yang mempengaruhi harga diri pada remaja seperti kondisi fisik, intelegensi, jenis kelamin dan lingkungan. Pada saat masih anak-anak lingkungan keluarga adalah lingkungan yang sangat berpengaruh pada anak khususnya orangtua.

Orangtua cenderung tidak menyadari akan kemampuan anak mereka. Beberapa orangtua justru dengan cepat memberikan label bahwa anak mereka "nakal", "kurangajar", "bodoh", dan lain sebagainya. Pada saat orangtua melabeling dengan perkataan negatif, orangtua berharap anak mengerti dan merubah perilakunya. Dampak dari terlalu melabeling anak dengan perkataan negatif, anak akan tumbuh menjadi anak yang memiliki harga diri rendah atau merasa diabaikan.

Saat memasuki masa perkembangan dari anak menuju remaja, remaja sudah mulai menyadari bahwa aktivitas apa saja yang ia lakukan berkaitan dengan kehidupan nyata tidak lagi sama dengan kehidupan anak-anak yang didominasi dengan permainan. Pada masa remaja individu mulai menyadari bahwa kesuksesan-kesuksesan dan kegagalankegagalan yang dialami di masa remaja merupakan prediktor untuk keberhasilan hidup di masa dewasa (Santrock, 2007). Individu yang memiliki keterikatan yang lebih dekat dengan orangtua mereka dan yang lebih terikat dan diterima oleh orangtuanya akan memiliki tingkat harapan yang lebih tinggi (Shorey et al, 2003).

Di saat orangtua menjalin hubungan yang efektif dengan anak, anak akan lebih merasa dihargai oleh orangtuanya. Secara tidak langsung di dalam perhatian dan keterlibatan orangtua membentuk karakter anak menjadi anak yang penuh harapan. Anak lebih merasa bahwa dirinya berharga dan kehidupannya memiliki banyak makna. Anak akan lebih memandang bahwa masa depannya cemerlang dan indah. Fakta mengatakan bahwa orang-orang yang memiliki harapan lebih berkompeten untuk mencapai tujuan mereka, membantu mereka menghadapi tantangan, kesulitan dan selalu berfokus pada strategi penanggulangan masalah serta membawa banyak hasil positif dalam kesehatan mental dan prestasi akademik (Shorey et al, 2003). Penelitian pada harapan dan harga diri menunjukkan bahwa harapan memiliki dampak positif pada harga diri (Barnum et al, 1998). Reaksi emosi yang terkait harga diri adalah konsekuensi dari proses berpikir yang penuh harapan. Selain itu, seperti harapan, harga diri juga diungkapkan berkaitan dengan penerimaan dan keterlibatan orangtua (Cohen et al, 2008).

Pada hasil penelitian terdahulu pada tahun 2014 yang dilakukan oleh Aydin, Sari, Sahin M., terdapat dampak langsung 
pada penerimaan/keterlibatan orangtua terhadap harga diri positif dan signifikan. Diindikasikan bahwa anak yang diterima, dilibatkan dan didukung oleh orangtua mereka memiliki pendapat yang lebih positif daripada diri mereka sendiri. Persepsi kasih sayang, penerimaan, keterlibatan dan dukungan yang berlanjut akan berdampak pada self-concept dan harga diri. Dampak langsung penerimaan/keterlibatan orangtua terhadap harapan juga didapat positif dan signifikan. Teori dan hasil temuan pada harapan dengan kualitas hubungan yang didirikan dengan orangtua pada tahap awal kehidupan sebagai dasar berfikir dengan penuh harapan pada masa dewasa. Dampak tidak langsung dari harapan sebagai mediator pada penerimaan/ keterlibatan orangtua terhadap harga diri signifikan. Persepsi penerimaan/ keterlibatan orangtua dapat meningkatkan level harapan pada anak dan peningkatan level harapan seorang anak berkontribusi untuk pengembangan harga diri. Teori mengenai harapan menunjukkan bahwa dasar tingkat harapan individu dewasa terletak pada hubungan dengan orangtua selama pada tahap-tahap awal kehidupan, dengan memiliki harga diri yang tinggi diharapkan anak akan lebih percaya diri sehingga ia mampu untuk mengekspresikan diri dengan baik. Saat bersosialisasi ia akan menanggapi pujian dan kritik dari lingkungan sekitar sebagai bahan pertimbangan. Saat mengalami kegagalan ia mampu menerima kegagalan tersebut dan tidak larut dalam kekecewaan tersebut dan selalu berpikir positif dan optimis.

Pendekatan humanistik menyatakan bahwa diri terdiri dari konsep-konsep yang unik untuk diri kita sendiri. Rogers (1959) percaya harga diri yang dikembangkan pada anak usia dini dan terbentuk dari interaksi anak dengan ibu dan ayah. Harga diri mencakup keyakinan (misalnya, "Saya berkompeten," "Saya layak") dan beberapa emosi seperti keberhasilan, putus asa, kebanggaan dan rasa malu (Coopersmith, 2000) sedangkan menurut Rosenberg (1979) harga diri adalah evaluasi diri seseorang terhadap kualitas atau keberhargaan diri sebagai manusia.

Dukungan sosial didefinisikan sebagai interaksi atau hubungan sosial yang membuat individu merasa lekat dengan sesorang ataupun kelompok menerima kasih sayang dan perhatian (Hobfoll \& Stokes, 1988). Dukungan orangtua adalah keterlibatan orangtua dalam berbagai bentuk termasuk pengasuhan di dalam rumah, lingkungan yang aman dan stabil, stimulasi intelektual, diskusi antara orangtua dan anak, dan model yang baik. Gecas (1986) mencatat bahwa dukungan dari ibu dapat memunculkan perasaan berharga pada anak, sedangkan dukungan dari ayah dapat mengembangkan potensi anak. Grolnick (2009) mengemukakan bahwa parenting memiliki pengaruh yang besar pada perkembangan kepribadian remaja. Terdapat tiga dimensi parenting yaitu parental autonomy support, parental involvement dan parental structure.

Snyder (2002) mendefinisi-kan harapan adalah keseluruhan dari kemampuan yang dimiliki individu untuk menghasilkan jalur mencapai tujuan yang diinginkan, bersamaan dengan motivasi yang dimiliki untuk menggunakan jalurjalur tersebut. Harapan didasarkan pada harapan positif dalam pencapaian tujuan. Menurut Weil (2000) dalam penelitiannya mengemukakan bahwa terdapat beberapa faktor yang dapat mempengaruhi harapan, yaitu dukungan sosial, kepercayaan religius dan kontrol.

Dalam penelitian yang dilakukan oleh Aydin et al (2014) yang meneliti 
hubungan Penerimaan/keterlibatan orangtua terhadap harga diri pada mahasiswa Karadeniz Technical University, menemukan bahwa ada hubungan positif antara penerimaan/ keterlibatan orangtua dengan harga diri. Penerimaan/keterlibatan yang digunakan dalam penelitian Aydin et al (2014) lebih berfokus pada pola asuh orangtua dimana di dalam skala pola asuh orangtua tersebut hanya mengungkap Penerimaan/keterlibatan orangtua dan pengawasan orangtua. Kebanyakan remaja merasa bahwa perilaku dan keputusan yang mempengaruhinya berada di bawah kendali orangtua mereka, dan semakin rendah harga diri remaja tersebut. Persepsi dukungan orangtua yang hangat dan yang mampu menegaskan pesan-pesan yang akan disampaikan dapat diinternalisasikan oleh remaja, dan hal tersebut menghasilkan perasaan harga diri yang tinggi (Plunkett et al, 2007). Orangtua yang memaksakan pilihan mereka pada anak-anaknya, dan anak gagal dalam mewujudkan harapan orangtuanya akan berakibat pada demotivasi dan mengecewakan untuk anak (Roberts, 2013).

Pada penelitian yang dilakukan oleh Heaven dan Ciarrochi (2008) menemukan bahwa gaya pengasuhan authoritative dan authoritarian memiliki korelasi yang tinggi pada harapan. Harapan pada anak dibentuk oleh dukungan social terutama oleh orangtua. Orangtua yang mendukung dan terlibat langsung dengan anak mereka, anak akan memiliki harapan yang lebih tinggi dibandingkan dengan anak yang tidak memiliki kedekatan emosioanl dengan orangtua mereka.

Harga diri juga dikenal membangun dan berfokus pada evaluasi pada nilai diri, sedangkan harapan berfokus pada keyakinan bahwa seseorang dapat mencapai tujuan penting dalam hidup.
Harapan mampu menjadi prediktor dari emosi positif dan untuk menentukan kelas (Ciarrochi et al., 2007). Terdapat korelasi yang positif antara harga diri dan harapan karena harga diri mampu meningkatkan level motivasi individu (Aspinwall \& Taylor, 1992). Semakin baik evaluasi diri yang dilakukan oleh individu itu sendiri makan mereka semakin yakin bahwa tujuan yang diinginkannya akan tercapai. Hal ini dikarenakan mereka percaya bahwa mereka layak mencapai tujuan tertentu karena mereka memiliki harga diri yang lebih tinggi. Kegigihan meningkat karena individu dengan harga diri yang tinggi yakin pada kemampuannya untuk memperoleh hasil tertentu dam memiliki harapan yang besar untuk mencapainya (Di Paula \& Campbell, 2002). Penelitian yang dilakukan di Brazil juga menemukan bahwa terdapat korelasi yang positif antara optimisme, harapan dan harga diri (Pacico et al, 2013) hal tersebut sama seperti penelitian yang dilakukan oleh Wong \& Lim (2009) yang menemukan bahwa terdapat korelasi positif dengan korelasi antara 0,50-0,60 antara harapan, optimis dan harga diri.

Aydin et al (2014) menemukan dalam penelitiannya bahwa orangtua yang menerima dan terlibat dengan anak akan menumbuhkan harapan pada remaja. Harapan yang tinggi pada remaja akan menghasilkan optimisme, kontrol diri, kemauan memecahkan masalah, daya saing dan harga diri pada remaja.

\section{METODE}

Subjek Penelitian adalah remaja berusia sekitar 12-15 tahun dan tinggal bersama orangtua sebanyak 50 subjek dan dilakukan di SMP Kartika IV-8 Malang.

Instrumen Penelitian disiapkan oleh peneliti dan berisikan pertanyaanpertanyaan mengenai remaja tersebut 
seperti nama, jenis kelamin, usia, kelas, anak ke - dan pekerjaan orangtua.

Alat ukur skala harga diri dikembangkan oleh Morris Rosenberg (1965) yang digunakan untuk mengukur harga diri secara umum. Rosenberg Self Esteem Scale (RSES) terdiri dari 10 aitem dengan empat pilihan jawaban menggunakan skala likert (sangat tidak setuju sampai sangat setuju) dengan contoh aitem "saya bersikap positif terhadap diri saya sendiri”. RSES memiliki nilai reliabilitas sebesar 0,870 dan validitas aitem correlation berkisar antara 0,496 -0,711 ( $\mathrm{r}$ tabel $=0,235)$. Hasil pengujian menunjukkan bahwa semua aitem valid dan reliabel.

Pada penelitian ini dukungan orangtua kepada subjek diukur dengan menggunakan Parents as Social Context Questionnaire (PASCQ) Child Report Skinner et al, 2005. Anak merespon dengan 4 poin pilihan jawaban dengan model likert (sangat tidak setuju sampai sangat setuju) dengan contoh aitem "Orang tua saya selalu bangga melihat saya". Skala ini memiliki nilai reliabilitas sebesar 0,925 dan validitas aitem correlation berkisar antara 0,200 - 0,791 $(\mathrm{r}$ tabel $=0,235)$. Hasil pengujian menunjukkan bahwa terdapat 2 aitem yang tidak valid dikarenakan $r$ hitung $<r$ tabel dan instrument reliabel.

Hope Scale for Children dikembangkan dari instrument State Hope Scale oleh Snyder (2003). Instrumen ini berjumlah 6 aitem terdiri dari 3 aitem yang mengukur willpower dan 3 aitem yang mengukur waypower. Anak merespon dengan 5 poin likert (tidak pernah sampai selalu) dengan contoh aitem "saya pikir hal-hal yang saya lakukan di masa lalu akan membantu saya di masa depan". Skala ini memiliki nilai Cronbach alpha sebesar 0,853 dan validitas aitem correlation berkisar antara $0,542-0,779$ ( $\mathrm{r}$ tabel $=0,235)$. Hasil pengujian menunjukkan bahwa semua aitem pada instrument harapan valid dan reliabel.

Peneliti mengadakan penelitian di SMP Kartika IV-8 Malang, pelaksanaan pengumpulan data melalui metode kuesioner berbentuk skala yang dalam hal ini ada tiga skala yang digunakan yaitu skala harga diri, skala dukungan orangtua, dan skala harapan. Subjek penelitian berjumlah 50 siswa. Setelah data terkumpul maka langkah selanjutnya dilakukan skoring untuk keperluan analisis data.

Adapun teknik analisa data yang digunakan dalam penulisan ini menggunakan pendekatan deskriptif kuantitatif yaitu mengumpulkan, merangkum serta menginterprestasi-kan data-data yang diperoleh yang selanjutnya diolah kembali sehingga diharapkan dapat menghasilkan gambaran yang jelas, terarah, dan menyeluruh dari masalah yang sedang dibahas. Hasil pengolahan data dianalisa dengan mempergunakan metode analisis regresi berganda dan uji Sobel.

\section{HASIL}

Dari hasil perolehan data yang diperoleh dari 50 subjek yang dilaksanakan di SMP Kartika IV-8 Malang. Dari penelitian yang dilakukan berikut deskripsi umum mengenai karakteristik dari subjek penelitian yaitu usia, jenis kelamin, status dalam keluarga, dan pekerjaan orangtua. Adapun rinciannya adalah sebagai berikut : 
Tabel 1 Deskripsi karakteristik subjek

\begin{tabular}{|c|c|c|c|c|}
\hline No. & Uraian & Kategori & Jumlah & Presentase \\
\hline \multirow[t]{4}{*}{1.} & Usia subjek & a. 12 tahun & 7 & $14 \%$ \\
\hline & & b. 13 tahun & 25 & $50 \%$ \\
\hline & & c. 14 tahun & 17 & $34 \%$ \\
\hline & & d. 15 tahun & 1 & $2 \%$ \\
\hline \multirow[t]{2}{*}{2.} & Jenis kelamin & a. Laki-laki & 20 & $40 \%$ \\
\hline & & b. Perempuan & 30 & $60 \%$ \\
\hline \multirow[t]{4}{*}{3.} & Urutan posisi & a. Sulung & 13 & $26 \%$ \\
\hline & & b. Tengah & 13 & $26 \%$ \\
\hline & & c. Bungsu & 16 & $32 \%$ \\
\hline & & d. Tunggal & 8 & $16 \%$ \\
\hline \multirow[t]{2}{*}{4.} & Pekerjaan Ayah & a. Bekerja & 50 & $100 \%$ \\
\hline & & b. Tidak bekerja & - & - \\
\hline \multirow[t]{2}{*}{5.} & Pekerjaan Ibu & a. Bekerja & 23 & 46 \\
\hline & & b. Tidak bekerja & 27 & 54 \\
\hline
\end{tabular}

Sebelum dilakukan uji hipotesis, terlebih dahulu dilakukan uji asumsi untuk memastikan bahwa data bebas dari semua asumsi klasik. Berdasarkan output test of normality dengan menggunakan Shapiro Wilk, diperoleh nilai signifikansi sebesar
0,$051 ; 0,066 ; 0,237>0,05$ maka dapat disimpulkan bahwa data berdistribusi normal. Berdasarkan output ANOVA Table, menunjukkan bahwa data linier dikarenakan taraf signifikansi 0,000 $(\mathrm{p}<0,05)$.

Tabel 2 Hasil uji regresi X ke Y, X ke M, dan M ke Y

\begin{tabular}{lccc}
\hline Hubungan & $\mathrm{r}$ & $\mathrm{t}$ & $\mathrm{p}$ \\
\hline Dukungan Orangtua --------> Harga Diri & 0,875 & 12,492 & 0,000 \\
Dukungan Orangtua ------> Harapan & 0,812 & 9,621 & 0,000 \\
\hline Harapan --------------------> Harga Diri & 0,825 & 10,095 & 0,000 \\
\hline
\end{tabular}

Berdasarkan tabel tersebut diketahui bahwa dukungan orangtua berkorelasi positif dengan harga diri sebesar 0,875 $(\mathrm{t}=12,492 ; \mathrm{p}=0,000)$. Dukungan orangtua berkorelasi positif dengan harapan sebesar $0,812(\mathrm{t}=9,621 ; \mathrm{p}=0,000)$. Harapan juga berkorelasi positif dengan harga diri sebesar $0,825 \quad(t=10.095 ; \quad \mathrm{p}=0,000)$, Sehingga dapat disimpulkan bahwa hipotesis 1, 2, dan 3 yang diajukan diterima. 


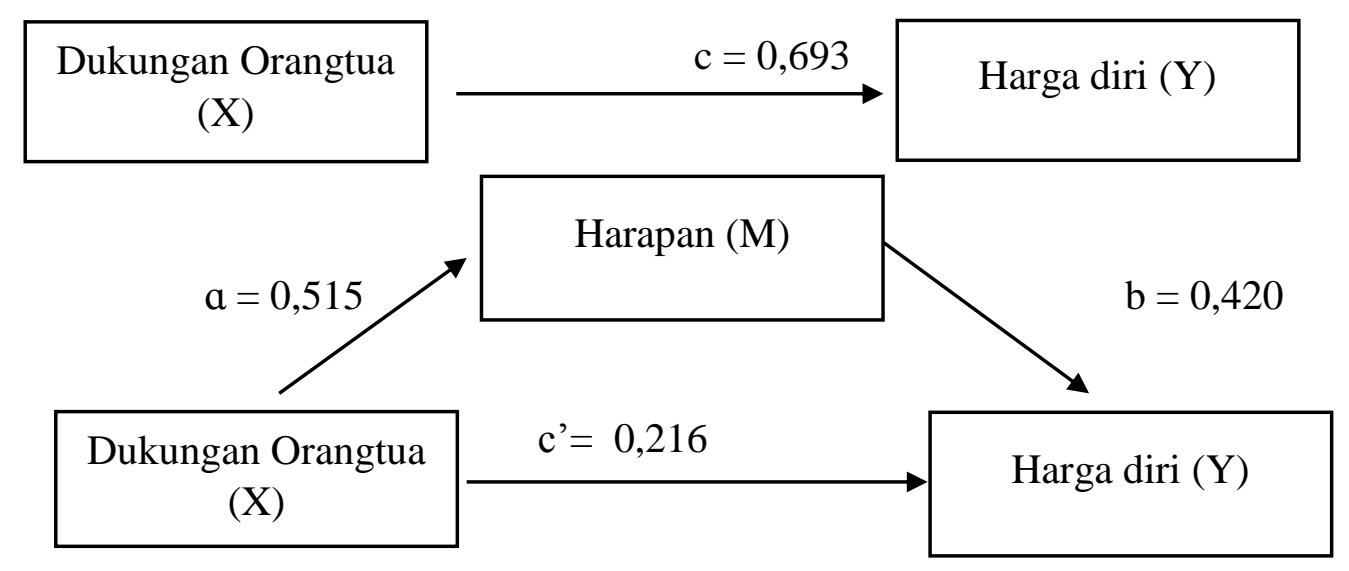

Gambar 1

Tabel 2 Hasil analisis regresi berganda

\begin{tabular}{lcccc}
\hline Hubungan & $\mathrm{B}$ & $\mathrm{Se}$ & $\mathrm{p}$ & Koefisien \\
\hline Dukungan Orangtua -----> Harapan & 0,515 & 0,054 & 0,000 & $\mathrm{a}$ \\
\hline Harapan ----------------> Harga Diri & 0,420 & 0,138 & 0,004 & $\mathrm{~b}$ \\
\hline Dukungan Orangtua -----> Harga Diri & 0,693 & 0,055 & 0,000 & $\mathrm{c}$ \\
\hline
\end{tabular}

$\mathrm{B}=$ Koefisien regresi, $\mathrm{Se}=$ Standart Error

Setelah dianalisis besarnya koefisien regresi unstandardized pada model hipotesis ditemukan bahwa dukungan orangtua berdampak langsung pada harapan sebesar 0,515 $(\mathrm{p}=0,000)$, harapan berdampak langsung pada harga diri sebesar $0,420 \quad(\mathrm{p}=0,004)$ dan dukungan orangtua berdampak langsung pada harga diri sebesar $0,693(\mathrm{p}=0,000)$ yang berarti signifikan secara statistik.

- Dampak tidak langsung dari dukungan orangtua melalui harapan terhadap harga diri

$=\mathrm{a} \times \mathrm{b}=0,515 \times 0,420=0,216$ (koefisien regresi parsial c')

- Dampak total dukungan orangtua melalui harapan terhadap harga diri $=c^{\prime}+c=0,216+0,693=0,909$
Harapan secara signifikan memediasi hubungan antara dukungan orangtua dengan harga diri. Dengan demikian standard error ab dapat dihitung sebagai berikut :

$$
\begin{aligned}
S a b & =\sqrt{b^{2} S a^{2}+a^{2} S b^{2}+S a^{2} S b^{2}} \\
& =0,075
\end{aligned}
$$

Sehingga Nilai $Z^{a b}$ dapat dihitung sebagai berikut :

$$
\begin{aligned}
Z^{a b} & =\frac{a b}{S_{a b}} \\
& =\frac{0,515 \times 0,420}{0,075}=2,884
\end{aligned}
$$

Hasil uji sobel menunjukkan hasil kalkulasi $\mathrm{Z}=2,884>1,96$ (nilai $\mathrm{z}$ mutlak) 
dan salah satu syarat terpenuhinya efek mediasi adalah $\mathrm{c}^{\prime}<\mathrm{c}$ yang berarti variabel mediator harapan dinilai secara signifikan memediasi hubungan antara dukungan orangtua dengan harga diri.

\section{DISKUSI}

Penelitian ini bertujuan untuk mengetahui hubungan antara dukungan orangtua dan harga diri dengan harapan sebagai variabel mediator dan hasil penelitian ini menunjukkan bahwa adanya dampak langsung dari dukungan orangtua pada harga diri signifikan secara statistik. Hasil penelitian remaja dapat diindikasikan bahwa remaja yang didukung oleh orangtua mereka memiliki anggapan yang lebih positif daripada remaja yang tidak didukung oleh orangtuanya. Penelitian sebelumnya yang dilakukan oleh Aydin et al (2014) menemukan bahwa penerimaan/keterlibatan orangtua dan dukungan yang berlanjut sampai dewasa akan berdampak pada konsep diri dan harga diri. Pada hasil penelitian ini menunjukkan bahwa terdapat dampak langsung dari dukungan orangtua dengan harapan dan signifikan secara statistik.

Teori dan hasil temuan menjelaskan bahwa harapan dengan kualitas hubungan yang didirikan antara orangtua dan anak pada tahap awal perkembangan anak dapat menjadi acuan anak berfikir dengan penuh harapan hingga dewasa nanti. Pada penelitian sebelumnya yang dilakukan oleh Shorey et al (2003) pada mahasiswa menemukan bahwa mahasiswa yang dekat dan diterima baik oleh orangtua mereka akan menjadi lebih penuh harapan, hal tersebut sesuai dengan hasil pada penelitian ini. Day et al (2010) menemukan bahwa terdapat hubungan yang positif antara harapan dan kepribadian ekstrovert, individu dengan kepribadian ekstrovert cenderung memiliki nilai yang tinggi pada harga diri. Orangtua yang mendukung dan selalu memantau anaknya dalam hal kehidupan sehari-hari memiliki hubungan yang positif dan signifikan terhadap efikasi diri dan harga diri (Frank et al, 2010)

Pada penelitian ini juga mengkaji peran harapan sebagai mediator dukungan orangtua terhadap harga diri. Hasil yang didapat adalah harapan memiliki hubungan yang signifikan dengan dukungan orangtua dan harga diri. Dengan kata lain dukungan orangtua dapat meningkatkan level harapan pada remaja dan peningkatan level harapan tersebut berkontribusi untuk pengembangan harga diri remaja. Teori mengenai harapan menunjukkan bahwa dasar tingkat harapan individu dewasa terletak pada hubungan orangtua selama pada tahap-tahap awal kehidupan. Salah satu hasil yang positif dari harapan adalah terbentuknya harga diri.

\section{SIMPULAN DAN SARAN}

Harapan adalah konsep secara keseluruhan dari kemampuan yang dimiliki individu untuk menghasilkan jalur dalam mencapai tujuan yang diinginkan, dengan didorong motivasi yang dimiliki untuk menggunakan jalurjalur tersebut. Harapan mampu membuat individu menjadi lebih optimis dalam menjalankan kehidupan. Harapan dan harga diri mulai dibentuk pada tahap awal-awal kehidupan dan pasti lingkungan terdekat yaitu orangtua sebagai pembentuknya, sehingga dukungan orangtua sangat penting dalam membangun harapan dan membentuk harga diri anak yang akan dibawa sampai dewasa nanti. Saran peneliti adalah saat ini orangtua sibuk untuk memenuhi kebutuhan biologis anak tanpa memikirkan kebutuhan psikologis anak. Orangtua yang lebih mendukung, 
menerima dan terlibat langsung pada kehidupan anak hingga remaja akan mampu menumbuhkan sikap-sikap positif pada anak dan hal tersebut akan dibawa sampai dewasa seperti optimis, pemecahan masalah, dan menghargai orang lain.

Diharapkan peneliti selanjutnya dapat lebih detail pada aspek dukungan orangtua dengan bentuk seperti apa yang mampu meningkatkan harga diri dan harapan pada remaja. Peneliti selanjutnya juga bisa memadankan dengan gaya pola

\section{DAFTAR PUSTAKA}

Aspinwall, L. G., \& Taylor, S. E. (1992). Modeling Cognitive Adaptation: A Longitudinal Investigation of the Impact of Individual Differences and Coping on College Adjustment and Performance. Journal of Personality and Social Psychology, 61, 755-765.

Ariyani, A. (2004). Perbedaan hope dan harga diri antara remaja yang pernah menggunakan narkoba dan remaja yang tidak pernah menggunakan narkoba. (Tesis, magister Profesi Psikolog Klinis Dewasa). Depok : Fakultas Psikologi Universitas Indonesia.

Aydin B., Sari Serkan V., Sahin M., (2014). Parental Acceptance/Involvement, SelfEsteem and Academic Achievement: The Role of Hope as a Mediator. Cumhuriyet International Journal of EducationCIJE, 3(4), 37-48.

Barnum, D. D., Snyder, C. R., Rapoff, M. A., Mani, M. M. \& Thompson, R. (1998). Hope and social support in the psychological adjustment of asuh orangtua (otoritatif, otoriter, permisif atau demokratis) sehingga semakin memperkaya ilmu dan subjek penelitiannya dapat lebih diperbanyak sehingga mampu di generalisasikan hasilnya pada studi yang sama. Keterbatasan lain pada penelitian ini adalah bahwa data yang dikumpulkan dari subjek yang dipilih melalui random sampling dalam satu sekolah, sehingga diharapkan peneliti selanjutnya dapat mengumpulkan data dari remaja di lingkungan yang lebih luas.

children who have survived burn injuries and their matched controls. Children's Health Care, 27(1), 1530.

Ciarrochi, J., Heaven, P. C. L.,\& Davies, F. (2007). The impact of hope, selfesteem, and attributional style on adolescents' school grades and emotional well-being: a longitudinal study. Journal of Research in Personality, 41, 11611178.

Ciarrochi, J., Heaven, P. C. L., \& Supavadeeprasit, S. (2008). The link between emotion indentification skills and socioemotional functioning in early adolescence: a one-year longitudinal study. Journal of adolescence, 31, 564-581.

Cohen, M., Mansoor, D. Gagin, R. \& Lorber, A. (2008). Perceived parenting style, self- esteem and psychological distress in adolescents with heart disease. Psychology, Health \& Medicine, 13(4), 381-388.

Coopersmith, S. (2000). The Antecedents of self-esteem. New York: W.H. Freeman 
Day, L., Hanson, K., Maltby, J. , Proctor, C. \& Wood, A. (2010). Hope uniquely predicts objective academic achievement above intelligence, personality, and previous academic achievement. Journal of Research in Personality, 44 (4), 450-453.

Di Paula, A., \& Campbell, J. D. (2002). Self-Esteem and Persistence in the Face of Failure. Journal of Personality and Social Psychology, 83, 711-724.

Frank, G., Plunkett S. W., \& Otten M, P. (2010). Perceived Parenting, SelfEsteem, and General Self Efficacy of Iranian American Adolescents. $J$ Child Fam Stud, 19, 738-746.

Gecas, V., \& Schwalbe, M. L., (1986). Parental Behavior and Adolescent Self-Esteem. Journal of Marriage and Family, 48, 37-46.

Grolnick, W.S. (2009). The role of parents in facilitating autonomous selfregulation for education. Theory and Research in Education, 7 (2), 164-173.

Heaven, P., \& Ciarrochi, J., (2008). Parental Style, Gender and the Development of Hope and SelfEsteem. European Journal of Personality, 22, 707-724.

Hobfoll, S.E., \& Stokes, J.P. (1988). The process and mechanics of social support. Handbook of personal relationships: Theory, research and interventions, 497-517.

Pacico, J.C., Zanon, C., Bastianello, M. R., \& Hutz, C.S. (2013). Adaptation and Validation of the Dispotitional Hope Scale for Adolescents.
Psicologia: Reflexão e Critica. 26. 488-492

Plunkett, S.W., Henry, C. S., Robinson, L. C., Behnke, A., \& Falcon, P. C., (2007). Adolescent Perceptions of Parental Behaviors, Adolescent Self-Esteem, and Adolescents Depressed Mood. Journal of Child and Family Studies, 16, 760-772.

Roberts, S.O., (2013) The relationship between parental involvement and mathematics achievement in struggling mathematic learners. New York: University Press

Rogers, C. (1959). A theory of therapy, personality and interpersonal relationships as developed in the client-centered framework. In (ed.) S. Koch, Psychology: A study of a science. Vol. 3: Formulations of the person and the social context. New York: McGraw Hill.

Rosenberg, M. (1979). Conceiving the self. New York : Basic Books.

Santrock, J. W. (2007a). Perkembangan anak edisi kesebelas jilid I. Jakarta: Erlangga.

Shorey, H.S., Snyder, C. R., Yang, X. \& Lewin, M.R. (2003). The role of hope as a mediator in recollected parenting, adult attachment and mental health. Journal of social and Clinical Psychology, 22(6), 685715.

Skinner, E., Johnson, S., \& Snyder, T. (2005). Six dimension of parenting: A Motivational model. Parenting: Science and Practice,5(2), 175-225.

Snyder, C.R. (2002). Hope Theory: Rainbows in the minds. 
Psychological Inquiry, 13 (4), 249275.

Snyder, C.R. (2003). Measuring Hope in Children. Indicator of Positive Development Conference.

Snyder, C. R., Hoza, B., Pelham, W. E., Rapoff, J., Ware, L., Danovsky, M., Highberger, L., Rubinstein, H., \& Stahl, K. (1997). The development and validation of the children's hope scale. Journal of Pediatric Psychology, 22, 399-421.

Weil, C.M (2000). Exploring Hope in Patients with End Stage Renal Disease on Chronic Hemodialysis. ANNA Journal, 22, 219-223.

Wong, S. S., \& Lim, T. (2009). Hope versus Optimism in Singaporean Adolescents: Contributions to Depression in Life Satisfaction. Personality an Individual Differences, 46, 648-652. 